\title{
'The choice is made from no choice': What motivates Libyan EFL teachers to work in times of change?
}

Suwaed, Hameda $\bowtie$

Sabratha University, Libya (hamedasuwaed@gmail.com)

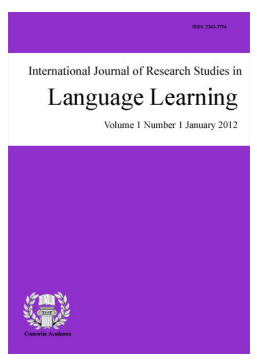

Accepted: 20 April 2018

ISSN: 2243-7754 Online ISSN: 2243-7762

\section{Abstract}

Libya is currently experiencing dramatic economic, social and political challenges. These challenges have a significant impact on the educational system. These challenges affect the teachers' academic, professional and daily lives. Consequently, some teachers feel less motivated to teach. Most English as a foreign language (EFL) research has investigated students' motivation, but there is very little research on teachers' motivation, especially in Libya. Thus, this study aims to investigate the factors that motivate EFL college teachers in Sabratha College of Arts and methods to enhance their motivation. Semi structured interviews with twelve teachers were used to collect data in this study. The findings of the study showed that, among the intrinsic, extrinsic and altruistic reasons, passion about teaching, collegiality, and enjoyment of working with students were considered the most important motivating key factors.

Keywords: altruistic; collegiality; extrinsic; intrinsic; teachers' motivation 


\section{'The choice is made from no choice': What motivates Libyan EFL teachers to work in times of change?}

\section{Introduction}

Teachers play a vital role in most educational institutions. Teachers give an institution its credibility and help achieve its educational goals. In addition, they have a great impact on their students' lives, motivation and attitudes. Teachers are expected to prepare, explain and do all the activities that are related to teaching and assessment. When it comes to teachers at Libyan colleges, the situation is more challenging because they are responsible for designing their courses and selecting the material for their students. At the same time, they are expected to demonstrate high performance, conduct research and participate in international conferences. Thus, being a teacher at a Libyan college is a very demanding profession. Further, the situation for English language teachers is not any better. They have to deal with issues related to their students' levels, mixed abilities and the influence of their first language (Suwaed, 2014). Nowadays, EFL teachers face more challenges and have heavier responsibilities than before, and research shows that teaching is one of the most stressful jobs in comparison to other professions (Adams, 2001). As a consequence, even the best teachers experience moments of frustration and consider leaving the teaching profession to do administrative work. In the literature, there has been much research on students' motivation but little research on teachers' motivation (Kazerouni \& Sadighi, 2014). Thus, the aim of this study is to investigate this area of neglect.

\section{Literature Review}

\subsection{Motivation and its types}

Motivation has been generally defined as the energy or drive that moves people to do something by nature. With regard to teachers' motivation, Sinclair (2008, p. 37) defines it as something that determines 'what attracts individuals to teaching, how long they remain in their initial teacher education courses and subsequently the teaching profession, and the extent to which they engage with their courses and the teaching profession'. Dörnyei (2001, p. 156) states that teachers' motivation is one of the vital factors that has a direct influence on students' motivation to learn. Williams and Burden (1997) identify two dimensions of motivation: initiating motivation, which is mainly concerned with the reasons for doing something, and sustaining motivation referring to the effort for sustaining motivation in doing something. Accordingly, motivation determines the reasons why people decide to do something and how long people continue the activity.

Dörnyei and Ushioda (2011) categorize teachers' motivation into four main components: intrinsic motivation, which is related to 'inherent interest of teaching'; social contextual factors, which are related to the 'impact of external conditions'; temporal dimension with an emphasis on sustainable commitment; and demotivating factors, which are related to challenges and constrains. In addition, Praver and Oga-Baldwin (2008) divide teachers' motivation into two types: 1) direct motivating factors (intrinsic motivation and extrinsic motivation) and 2) indirect motivating factors (autonomy, working environment and institutional support). They mentioned that these factors play a crucial role in the maintenance of teachers' motivation over their career.

According to Bastick (2000) and Sharif, Hossan, and McMinn (2014) motivation can be categorized into three types: 1) extrinsic that includes "lower-order needs" of Maslow's Theory (Mau, Ellsworth, \& Hawley, 2008, p.49), such as working conditions, salary and social status 2) intrinsic "that are associated with higher-order needs" of Maslow's Theory (Mau et al., 2008, p. 49), such as achievements, enjoyment of teaching and responsibility, 3) altruistic that 'responsibility, 3) altruistic that 'makes a difference to young lives' and contributing to the society (Sharif et al., 2014). 


\subsection{Theories of Motivation}

Due to the complexity of motivation, most researchers are selective in their research by applying different motivation theories. According to Johnson (1986), there are three theories of motivation that individuals' motivation is based on. The expectancy theory states that individuals try harder if they expect a reward worth working for, such as a promotion, than if there is none. The equity theory states that individuals are demotivated if they are unfairly treated for their efforts and achievement. Finally, the job enrichment theory states individuals become more productive if the work is challenging.

According to the expectancy theory, there is a link between the effort and reward. Teachers are thought to be more motivated if their effort is rewarded. Consequently, equity and fairness at work is linked to high motivation. Administrators should make sure that teachers are rewarded and professionally challenged (Koran, 2014). Another important factor in teacher's motivation is teacher efficacy, which is the 'belief of teachers that they can have a positive effect on their students' progress and success. Teachers with a high sense of efficacy have motivation for teaching and willingness to deal with students' misbehavior (Pajares, 1997).

Moreover, Tziava's (2003) research about the factors that motivate and demotivate Greek EFL teachers, shows that Greek teachers are motivated by working with young students, whereas they are demotivated by their payment. Also, in a study conducted in Mexico, Johnson (2001) investigated the factors that influence Mexican EFL teachers' motivation. She found that training, teaching students and having supportive working environment were the most important factors that motivated Mexican teachers. The findings of Kiziltepe's study (2006), which was conducted in Turkey, show that administration and students are major factors that demotivate high school teachers. In another study by the same author (2008) about the factors that demotivate university teachers, she found that less time for research was the main factor. Other support can be found in Sugino's research (2010) about the factors that motivate EFL Japanese college teachers. The findings show that most of the factors are related to students' attitudes. Similarly, Karavas' study (2010) of Greek EFL teachers' motivation indicated that the main sources of teachers' stress and demotivation were the students' low motivation and misbehavior.

In addition to these external factors, Sergiovanni (1967) mentions that teachers obtain their motivation through inspiring their students, feeling important and experiencing recognition. Also, according to Kaiser (1981), teachers' motivation might be enhanced when the teachers are allowed to choose their material and teaching methods. Dinham and Scott's (2000) findings show that students' academic achievements are one of the common motivators for teachers, among others. Moreover, most teachers feel motivated when their students achieve success and when they perform well on exams.

The work environment is also one of the factors that might motivate/demotivate ESL/EFL teachers. For example, Rocha (2012) investigated the factors that motivated eight English language teachers working at Eskisehir Osmangazi University Preparatory English Program and how their motivation could be enhanced. The findings showed that teachers were motivated by their colleagues, and the work place played a role as well. On the other hand, there are factors that demotivate teachers. Pennington (1995) mentions that the main factors that demotivated teachers were stress, heavy workloads, job stability and disagreement with teaching methods. Additionally, Doyle and Kim (1999) summarize the main factors that demotivate ESL/EFL teacher as follows:

$>\quad$ Lack of respect from administration

$>\quad$ Lack of advancement opportunities

$>\quad$ Lack of long term employment and job security

$>$ Overly heavy workloads

$>$ Separation and alienation of teachers

$>\quad$ Lack of rewards for creativity

$>\quad$ The malfunctioning of the educational system

$>\quad$ Lack of funding for projects

$>$ Lack of autonomy in the teaching and evaluation

$>$ Lack of appropriate teaching environment 
$>$ Over-commercializing textbooks

$>$ Discrepancies in teaching philosophies

$>\quad$ Lack of teacher training

$>$ Institution of team teaching and foreign assistant teacher

As a consequence of working in these conditions, teachers will lose their motivation, which will in turn affect their teaching practice. These factors might cause teachers to quit their jobs, Koran (2014). On the other hand, supportive work environments, colleagues, job security, training opportunities, and promotions are factors which increase teacher motivation (Mani, 2002).

Despite the various findings from studies conducted on ESL/EFL teachers' motivation to date, much still needs to be investigated. Additionally, few studies have investigated EFL teachers' motivation in the college context. This study aims to expand on the literature by investigating the factors that motivate Libyan EFL college teachers to continue working and how to enhance their motivation as Dörnyei (2003, p. 26) states that no researchers had listed "ways to motivate language teachers, even though a scientifically validated list of this sort would predictably be very useful and much sought after".

\section{Method}

\subsection{Participants}

The researcher met seventeen English language teachers who work in the Department of English, College of Arts, Sabratha University. Twelve of them agreed to participate in this study. The participants were two males and ten females. One holds a $\mathrm{PhD}$ and the other eleven are MA holders. Their teaching experience ranged from four to fifteen years.

\subsection{Data Collection and Analysis}

A qualitative approach was selected to investigate the factors that motivate Libyan EFL college teachers and how their motivation might be enhanced. Semi structured interviews were used because they have structured framework but are flexible for more follow up of responses (McDonough \& McDonough, 1997).

Data collection process - After receiving permission from the head of the department to interview the English language teachers, the researcher began the data collection. At the beginning of the interviews, the researcher informed the teachers about the purpose of the study and assured them that the information provided would be kept confidential. The interviews took place in the teachers' workplace. Some interviews lasted forty-five minutes, and some lasted thirty minutes. The interviews were conducted in English with occasional use of Arabic language.

Data Analysis - Once all twelve teachers were interviewed, the data was organized and coded around the main themes of the research: the factors that motivate EFL Libyan college teachers and how to enhance their motivation. The themes related to teachers' motivation were categorized into intrinsic, extrinsic and altruistic factors.

\subsection{Research Questions}

Although teachers' motivation has been an extensive topic of research, EFL college teachers' motivation is a neglected area of research in Libya. Most of the research studies have been conducted on students' motivation. Hence, using the Libyan EFL context, this study aims to investigate the following research questions:

$>$ What motivates Libyan EFL college teachers working in Sabratha College of Arts?

$>\quad$ How can the Libyan EFL college teachers' motivation be enhanced? 


\section{Findings and Discussion}

\section{What motivates Libyan EFL teachers working in Sabratha College of Arts?}

The results obtained in this research indicate that there are different intrinsic, extrinsic and altruistic factors that can have an impact on teachers' motivation.

4.1 The researcher has compiled a list of intrinsic factors (Table 1) that motivated the teachers:

\section{Table 1}

Lists the factors that the teachers considered their source of intrinsic motivation

\begin{tabular}{lc}
\hline \multicolumn{1}{c}{ Intrinsic motivations } & Frequency \\
\hline Love teaching & 8 \\
Bing born to be a teacher & 3 \\
I can motivate myself & 4 \\
Being knowledgeable & 2 \\
\hline
\end{tabular}

As shown in Table 1, most teachers said that they had chosen to be teachers because they love teaching. For example, teacher 9, with fifteen years of teaching experience as an EFL college teacher, affirmed that she has a strong passion to be a teacher. Moreover, teacher 4, with five years of experience, said that while still in primary school, she decided to become an EFL teacher. Also, three of the interviewed teachers who said they love being teachers also said that they were born to be teachers. Teacher 10, with eleven years of teaching experience, stated, "I cannot think of another job or another profession. I was born to be a teacher." T9 perceives her role in the class as a maestro; she stated, "The moment I enter the class, is the moment when the concert starts. It is like having some orchestra players and everyone should do their performance." Moreover, the teachers who stated that they were born to teach mentioned that they could motivate themselves. T9, with fifteen years of teaching experience, said, "I love teaching and it is something internal that I can be motivated despite all the challenges".

In reference to being knowledgeable and having teaching experience, knowledge comes with experience, but it does not mean that lack of experience means lack of knowledge or motivation. T8, who has been teaching for only five years, was one of the most motivated teachers who participated in this study. She stated, "I have knowledge and like to share it with my students." This finding is in consonance with Qayyum and Siddique (2003), who found in their research that teachers' competency motivated them to perform well.

In addition, the findings of this study are in consonance with Wadsworth's (2001) research, which involved 914 public and private school teachers in the USA. The research concluded that $96 \%$ of them decided to be teachers due to intrinsic reasons. Similarly, Doyle and Kim's (1999) research findings show that teachers in their study were also intrinsically motivated. These findings are in accordance with the results of other studies conducted in different contexts. For example, Kassabgy, Boraie, and Schmidt's (2001) findings, from their research that investigated ESL Egyptian and Hawaiian motivational factors, show that the teachers put more value on intrinsic aspects of their job.

\subsection{Although several intrinsic factors motivated many teachers who participated in the current study, few} extrinsic factors were mentioned in their answers:

\section{Table 2}

Lists the extrinsic factors

\begin{tabular}{lc}
\hline \multicolumn{1}{c}{ Extrinsic factors } & Frequency \\
\hline Colleagues & 8 \\
Work environment & 4 \\
Teaching at university & 2 \\
Salary & 2 \\
\hline
\end{tabular}


Although, most of the teachers who participated in this study mentioned that they love teaching internally and that keeps them motivated, they expressed their need to have supportive colleagues to maintain their motivation. According to Johnson (2001), having supportive colleagues is a main source of teachers' motivation. $\mathrm{T} 1$, with eleven years of teaching experience, said, "I cannot work if colleagues do not ask or show their work. It keeps you motivated and looking for something new." Additionally, working together with other teachers can also increase the teachers' motivation, according to the teachers who participated in this study. Nonetheless, they knew that teaching is a very demanding profession and they have busy schedules, so they need to find time to work like a team to share ideas and face challenges. T6, with four years of teaching experience, added, "I feel more motivated when I work with my colleagues as a team to prepare for an event or activities."

Along similar lines, having a friendly work environment is also considered an important factor that influences teachers' motivation. T3, with seven years of teaching experience, asserted that, "The place plays an important role for me. I like to work in a clean well-organized place." Similarly, Johnson's (2001) comment about the teachers in her study was that pleasant physical space was a source of motivation. Being a university teacher is the third extrinsic factor mentioned, and one that motivated three teachers who had previously worked as secondary school English teachers. $T 1$ said, "Teaching in the university makes me more motivated compared with my previous job. Students are more mature, more academic work that is really good for my career." The last extrinsic factor that motivated some teachers was the salary. T5, with five years of teaching experience, said, "I am not motivated to teach but I cannot think of another profession because I need the salary." T3 added, "There are many challenges in teaching but the good payment keeps me motivated."

\subsection{The teachers' who participated in this study mentioned the following three altruistic factors that motivate}

them to teach:

\section{Table 3}

Lists of altruistic factors

\begin{tabular}{lc}
\hline \multicolumn{1}{c}{ Altruistic factors } & Frequency \\
\hline I enjoy working with students & 8 \\
Students need my help to learn & 3 \\
I want to make a difference & 2 \\
\hline
\end{tabular}

The interviews with the teachers revealed that students are the most motivating factor. Dörnyei (2001) mentioned that if teachers were motivated to teach, their students would be motivated too. However, three teachers who participated in the current study stated that their students motivate them. T2, with seven years of teaching experience, stated, "My students motivate me. When they understand what I teach, I get motivated." Additionally, T8 added, "Students shape the way I teach. They form the whole lecture." In addition, T9 added, "When my students speak using my own words and having my sense of humor, when they stop asking about exams and just enjoy the lecture, that motivates me." T4 added, "My students body language and facial expressions could tell if they are attentive and interested. That is necessary motivators for me."

Connie (2000) obtained similar results in her study that investigated Mexican EFL teachers' motivation. She found that the most important factors that motivated teachers were better performance among students and students' own motivation. However, T5, with five years of teaching experience, who appeared to be less motivated than the other teachers complained, "Even when I am motivated, students' misbehavior and low level makes me demotivated." The findings of this study are evidence that the relationship between teachers and students is a crucial source of motivation or de-motivation.

In addition, some teachers believe that their role is important in their students' learning process. T2 stated, "As you know English is not their first language. I have to explain for them, pronounce new words, and correct their mistakes. That gives importance to our job. Students cannot learn by themselves." Additionally, T8 added, 
'The choice is made from no choice': What motivates Libyan EFL teachers to work in times of change?

"The best part of the lecture for me is the end of the lecture when we summarize the main points and realize that they got the new information that I explained for them, that motivates me."

Considering the unstable political and economic situation in Libya, some teachers mentioned that they are motivated to teach because they think that it is their duty to serve the country and help students through difficult times, such as being displaced or those who lost family members in the clashes. T9 stated, "It is our duty to work now under the difficult circumstances. Our students need us so do our country." T12, with eleven years of teaching experience, added, "I try not be influenced by what is going on and show my students that the future will be ok. That makes difference in their motivation." This is consistent with Kyriacou and Coulthard's (2000) findings, which showed that teachers chose teaching because they believed that they could contribute to their society.

\section{How can the Libyan EFL college teachers' motivation be enhanced?}

A list of factors related to extrinsic motives, was compiled (See Table 4). The list has been classified into three groups: working conditions, colleagues, and administrators. These extrinsic factors would enhance the teachers' motivation. Without them, the teachers felt somehow demotivated:

\section{Table 4}

The factors that might enhance teachers' motivation

\begin{tabular}{lc}
\hline \multicolumn{1}{c}{ Factors that might motivate teachers } & Frequency \\
\hline \multicolumn{1}{c}{ Colleagues } & \\
Getting support and feedback from colleagues & 5 \\
Supportive work environment $\quad$ Work conditions & 5 \\
Having well equipped classes & 5 \\
Having fast internet connection & 2 \\
Administration & \\
Being informed about plans, courses and new regulations & 9 \\
Professional development opportunities & 7 \\
Recognition & 3 \\
\hline
\end{tabular}

In the first group, collegiality was highly mentioned as an important factor that enhanced teachers' motivation. T4 affirmed, "Having supportive colleagues is necessary to keep me motivated." T9, added, "Nothing is better than working with motivated colleagues. They push you to work harder and share what you have."

These quotations above explain that support from colleagues is essential for teachers to enhance their motivation and to keep teaching and learning. The findings support Johnson's (2001) research, which affirmed that the support teachers received from colleagues was one of the factors that motivated them. The teachers in the current study need not only support, but also feedback and comments about their lesson plans and activities from colleagues. T3: said, "It is good to have someone to ask and check if I am doing well." Even those who had good teaching experiences thought that support and feedback were essential.

The present study supports Johnson's (2001) findings which showed that getting constructive feedback motivated the teachers. However, due to busy teaching schedules, this is not always applicable. T5 stated, "I like to discuss with my colleagues' issues related to our job, sometimes I need to ask for more examples or to check my understanding. However, everyone is busy and I feel shy to ask and that demotivates me because I need support." According to Shah (2012), this is common because teachers have busy schedules and heavy workloads in addition to their other responsibilities.

Koran (2014, p. 79) suggests, "Teachers should be provided with feedbacks to realize their weaknesses and strengths and positive efforts should be rewarded by the administration." T5 asserted, "Not having feedback from 
my colleagues, mainly my experienced colleagues, influences my teaching because I am not sure if I implemented the methods correctly or not. The opposite is true. When I have comments about my teaching I feel more interested to apply other new techniques."

In the second group, working conditions, the teachers mentioned two factors. Well- equipped classes was the first factor that could increase the teachers' motivation. T3 stated, "The facilities are important. When the class has the needed equipment, I feel more motivated to come and teach." Additionally, T8 mentioned, "ICT play role in my motivation. I like to use technology in my classes but it is not easy to use it." T3 added, "If we have the essential facilities, the teaching will be more interesting and we can use variety of supporting materials." Having fast internet connection was the second factor in working conditions that could increase some teachers' motivation. T4 thought, "It would be more beneficial if there is internet connection to use it in the classroom." Additionally, T12 thought that the internet would increase her motivation. The statements from the teachers who participated in this study supported the findings of Johnson's (2001) study, which showed that access to the internet increases teachers' motivation.

In the third group, administration, the first factor that could greatly increase the teachers' motivation was information about courses and plans. This factor was highly emphasized by the teachers who felt demotivated when they did not know what was going on. T2 stated, "It is really imperative when you do not know how they send colleagues for conferences or workshops. The criteria are not there. I feel really demotivated when I think that there is no chance of improvement for me." T7 added, "Teachers should be informed about courses and asked about their opinions. Chances should be open to all teachers.". This is consistent with Pennington's(1991) research findings, which showed that lack of support from the administration was one of the factors that demotivated teachers. The teachers in this study believed that having a clear idea about the criteria of nomination and being part of the decision process would help enhance their motivation. T9 stated, "Being a part of the team would motivate me. Getting involved in planning and being asked about what I need would motivate me. I don't like to feel like a stranger."

More professional development opportunities such as in-service training, workshops and seminars were the next factor in the group. It seemed to be an important factor that enhanced EFL teachers' motivation since it was the major concern for most of the teachers who participated in this study. T5 stated, "We need workshops about new teaching methods and how to deal with students. That would make me more knowledgeable and self-confident." T2 added, "Attending seminars and conferences make me more aware of how to improve my teaching practice and make it interesting and that make more motivated to teach'." This finding is consistent with Woodward (1992), who considered training as a motivational factor, and Dinham and Scott (2000), who thought that self-improvement opportunities and mastery of professional skills were among the common factors that boosted teachers' motivation. However, the teachers in this study complained about the limited opportunities available for their professional development. According to Koran (2014), this is a common finding in teachers' motivation research as teachers often lose their motivation if they are not provided with professional development opportunities.

Recognition is another factor that might help to enhance teachers' motivation. The discussion with the teachers in the interview shows that they would be more motivated if their efforts and achievements were fairly recognized and praised by the administration. These findings support the expectancy theory. Some teachers mentioned that they felt more motivated when their efforts were rewarded, and they were less motivated if their work was not equally compensated. T4 stated, "It makes difference in my interest when I have thank you card from my students. I wish if receive it from the department as well." This finding is in accordance with a study conducted by Ghenghesh (2013), which showed that receiving recognition at the university motivated teachers to perform better.

In sum, it appears that work environment factors such as collegiality, institutional support and opportunities for professional development have crucial influences on maintaining teachers' motivation. Teachers need 
'The choice is made from no choice': What motivates Libyan EFL teachers to work in times of change?

opportunities to work with each other because collegiality increases teachers' enthusiasm and reduces stress. It also makes the work meaningful and creates a sense of belonging according to Shah (2012). Tziava's (2003) findings also support the idea that a good relationship with colleagues motivates teachers. In addition, Ghenghesh $(2013$, p. 463) states that having the opportunity for training is considered a significant factor for teachers' motivation. All of these studies support the findings of this research: support from administrators and colleagues might be the main factor which leads to teachers' motivation or low motivation.

\subsection{Limitations}

This study investigated the motivational factors of twelve teachers working in Sabratha College of Arts and how to enhance their motivation. As this study was based on a small number, the research findings cannot be generalized to all EFL teachers in Libya. Also, the teachers represented only one group of EFL teachers in Libya. There are several other groups, such as high school teachers, private college teachers and education college teachers, and the findings of the study might have been different if the researcher had interviewed those other groups.

\section{Conclusion and Implications for Research}

This study aimed to investigate the factors that motivate Libyan EFL teachers to teach and how their motivation can be enhanced. After analyzing the data, the researcher concluded that the teachers were more intrinsically than extrinsically motivated, and the factors that might enhance their motivation were classified into three groups: working conditions, colleagues and administration. Through the discussions with the teachers and data analysis, it was noted that collegiality plays a crucial role in motivating teachers. That is to say, the participants need supportive colleagues that share ideas with them and guide them if needed. The administrators could also play an important role in the teachers' motivation if they are more open to the teachers, make them a part of the team and give them more responsibilities. The findings of this study revealed that, regardless of their teaching experience, most of the teachers obtained their motivation from teaching itself, their students and the opportunities to improve professional skills.

Based on the findings of this study, the researcher recommends the following:

$>\quad$ Providing opportunities for professional development such as in-service training, workshops and seminars

$>$ Administrative support, improved working conditions and teachers involvement in decision making might increase teachers' motivation

$>$ Teachers need to be provided with more opportunities to support each other, share their experiences, discuss the challenges that they face, and how to deal with challenges.

It can be said that this study was just the beginning of other studies to be conducted on Libyan EFL teachers' motivation. Through the data analysis and the discussion with the teachers, the researcher developed a few ideas for future research. Thus, this study recommends further research on different groups of teachers to give a better understanding of Libyan EFL teachers' motivation. Furthermore, the study needs to be duplicated at different universities to investigate whether the results would be significant. Additionally, it would be interesting if questionnaires could be used to involve a larger number of teachers. In addition, studies on teachers' motivation with regard to gender, age and teaching experience variables will be of great benefit.

Acknowledgment: I acknowledge the EFL college teachers who participated in the present study. I would like to express my special thanks for their precious time and their contribution to this research.

\section{References}

Adams, E. (2001). A proposed causal model of vocational teacher stress. Journal of Vocational Education and 
Suwaed, H.

Training, 53(2), 223-246. https://doi.org/10.1080/13636820100200153

Bandura, A. (1997). Self-efficacy: The exercise of control. New York: W.H. Freeman.

Bastick, T. (2000). Why teacher trainees choose the teaching profession: Comparing trainees in metropolitan and developing countries. International Review of Education, 6(3), 343-349. https://doi.org/10.1023/A:1004090415953

Dinham, S., \& Scott, C. (1998). A three-domain model of teacher and school executive career satisfaction. Journal of Educational Administration, 36 (4), 362-378. https://doi.org/10.1108/09578239810211545

Dorneyi, Z. (2001). Motivational strategies in the language classroom. Cambridge: Cambridge University Press. https://doi.org/10.1017/CBO9780511667343

Dornyi, Z. (2003). New themes and approaches in second language motivation reason. Annual Review of Applied Linguistics, 21, 43-59.

Dornyei, Z., \& Ushioda, E. (2010). Teaching and researching motivation (2nd ed). Pearson education.

Doyle, G., \& Kim, Y. (1999) Teacher motivation and Satisfaction in the United States and Korea. MEXTESOL Journal, 23, 35-48.

Connie, R. (2000). Factors influencing motivation and de-motivation of Mexican EFL teachers. Paper presented at the Annual Meeting of Teachers of English to Speakers of other Languages. Vancouver. Retrieved from ERIC database (ED 459605).

Ghenghesh, P. (2013). Job satisfaction and motivation: What makes teachers tick? British Journal of Education, Society \& Behavioral Science, 3(4), 456-466.

Johnson, C. R. (2001). Factors influencing the motivation and de-motivation in Mexican EFL teachers. MEXTESOL Journal, 25(1), 51-68.

Johnson, S. M. (1986). Incentives for teachers: What motivates, what matters. Educational Administration Quarterly, 22(3), 54-79. https://doi.org/10.1177/0013161X86022003003

Kaiser, J. S. (1981). Motivation deprivation: No reason to stay. The Clearing House: A Journal of Educational Strategies, Issues and Ideas, 55, 35-38. https://doi.org/10.1080/00098655.1981.9958204

Karavas, E. (2010). How satisfied are Greek EFL teachers with their work? Investigating the motivation and job satisfaction levels of Greek EFL teachers. Porta Linguarum, 14, 59-78.

Kassabgy, O., Boraie, D., \& Schmidt, R. (2001). Values, rewards and job satisfaction in ESL/EFL. In Z. Dörnyei \& R. Schmidt (Eds.), Motivation and second language acquisition (Technical Report \#23, pp. 213-237). Honolulu: University of Hawai' $i$, Second Language Teaching and Curriculum Center.

Kazerouni, N., \& Sadighi, F. (2014). Investigating Iranian female EFL teachers' motivation and job satisfaction level at public schools and private language institutes in Shiraz. International Journal on Studies in English Language and Literature, 2(8), 93-105.

Kiziltepe, Z. (2008). Motivation and demotivation of university teachers. Teacher and Teaching: Theory and Practice, 14, 515-530. https://doi.org/10.1080/13540600802571361

Koran, S. (2015). Analyzing EFL teachers' initial job motivation and factors affecting their motivation in Fezalar educational institutions in Iraq. Advances in Language and Literary Studies, 6(1), 72-80.

Kyriacou, C., \& Coulthard, M. (2000). Undergraduates' views of teaching as a career choice. Journal of Education for Teaching, 26(2), 117-126. https://doi.org/10.1080/02607470050127036

Mani, B. G. (2002). Performance appraisal systems, productivity, and motivation: A case study. Public Personnel Management, 31, 141-159. https://doi.org/10.1177/009102600203100202

Mau, W. C. J., Ellsworth, R., \& Hawley, D. (2008). Job satisfaction and career persistence of beginning teachers. International Journal of Educational Management, 22(1), 48-61. https://doi.org/10.1108/09513540810844558

McDonough, J., \& McDonough, C. (1997). Research methods of English language teachers. London: Arnold.

Pajares, F. (1997). Current directions in self-efficacy research. In M. Maechr \& P. Pintrich (Eds.), Advances in Motivation and achievement (pp. 1-49). Greenwich: JAI Press.

Praver, M., \& Oga-Baldwin, W. (2008). What motivates language teachers: Investigating work satisfaction and second language pedagogy. Polyglossia, 14, 1-8.

Pennington. M. (1995). Work satisfaction, motivation and commitment in teaching English as a second language. 
'The choice is made from no choice': What motivates Libyan EFL teachers to work in times of change?

Unpublished manuscript. University of Luton, UK.

Qayyum, A., \& Siddique, M. (2003). Let's enhance the performance of the teacher: A study of motivational techniques used by school heads. Journal of Elementary Education, 13, 21-28.

Rocha, E. (2012). Factors that motivate Turkish EFL teachers. International Journal of Research Studies in Language Learning, 2(2), 49-61.

Sergiovanni, T. (1967). Factors which affect satisfaction and dissatisfaction of teachers. Journal of educational administration, 5, 66-81. https://doi.org/10.1108/eb009610

Sharif, T., Hossan, C., \& McMinn, M. (2014). Motivation and determination of intention to become teacher: A case of B.Ed. students in UAE. International Journal of Business and Management, 9(5), 60-73. https://doi.org/10.5539/ijbm.v9n5p60

Shah, M. (2012). The importance and benefits of teacher collegiality in schools a literature review. Procedia-Social and Behavioral Science, 46, 1242-1246. https://doi.org/10.1016/j.sbspro.2012.05.282

Sinclair, C. (2008). Initial and changing student teacher motivation and commitment to teaching. Asia-Pacific Journal of Teacher Education, 36, 79-104. https://doi.org/10.1080/13598660801971658

Sugino, T. (2010). Teacher demotivational factors in the Japanese language teaching context. In Procedia Social and Behavioral Sciences, 3, 216-226. https://doi.org/10.1016/j.sbspro.2010.07.036

Suwaed, H. (2013). The challenges that Zawia English writing teachers face in teaching writing at the university level in Libya. College of Arts Journal, 17(3), 17-27.

Tziava, K. (2003). Factors that motivate and demotivate Greek EFL teachers (Unpublished doctoral dissertation). The University of Edinburgh, Edinburgh.

Wadsworth, D. (2001). Why new teachers choose to teach? Educational leadership, 58(8), 24-28.

Williams, M., \& Burden, R. (1997). Psychology for language teachers: A social constructivist approach. Cambridge: Cambridge University Press.

Woodward, T. (1992). Ways of training: Recipes for teacher training. Harlow: Longman. 
Suwaed, H. 